\title{
Pessoal Auxiliar em Odontologia Junto ao Sindicato dos Empregados em Estabelecimentos de Serviços de Saúde
}

Flávia S. Alves*, Dagmar de P. Queluz.

\section{Resumo}

Este estudo tem como objetivo identificar as clínicas odontológicas associadas ao Sindicato dos Empregados em Estabelecimentos de Serviços de Saúde, para um levantamento acerca de sua abrangência e relevância da aplicabilidade de suas funções ao longo do tempo. Os dados foram coletados em duas etapas: 1- no sindicato, as variáveis: Cadastro Nacional de Pessoa Jurídica (CNPJ) das clínicas odontológicas cadastradas, cidade e ano de cadastro no Sindicato. 2- Coletas online: Classificação Nacional de Atividades Econômicas (CNAE) no portal do Ministério da Fazenda; quantidade de processos trabalhistas em andamento, fornecida pela Certidão Eletrônica de Ações Trabalhistas (CEAT), no portal do Ministério da Justiça do Trabalho, a qual foi emitida no mesmo dia, para controlar uma possível variabilidade de resultados e ano de fundação das empresas, no portal de cada Prefeitura Municipal. Os resultados foram 62 clínicas odontológicas cadastradas no Sindicato. Indicaram que: metade das clínicas estão em Piracicaba, a média de fundação é de 11 anos, mais de $75 \%$ exercem atividade odontológica e apenas $32,25 \%$ estão com processos trabalhistas em andamento. Este estudo constatou o referido sindicato como defensor dos interesses da classe trabalhadora, pela condução de processos trabalhistas, independente da localização territorial, tempo de atividade e época de filiação a ele.

\section{Palavras-chave}

Sindicatos; Clínicas Odontológicas; Processo Legal.

\section{Introdução}

As empresas são caracterizadas, em geral, pela independência política e cultural, e estão dissociadas do Estado devido à autonomia econômica e de gestão. A despeito das entidades odontológicas, estas são integradas pelos conselhos e entidades profissionais, advindo dessas últimas, os sindicatos. Um Sindicato é uma associação de trabalhadores tendo como função defender os seus interesses, direitos profissionais e sua cidadania. O pessoal auxiliar em Odontologia tem este Sindicato dos Empregados em Estabelecimentos de Serviços de Saúde como representativo de sua categoria profissional.

Este estudo tem como objetivo identificar as clínicas odontológicas associadas ao Sindicato dos Empregados em Estabelecimentos de Serviços de Saúde, para um levantamento acerca de sua abrangência e relevância da aplicabilidade de suas funções ao longo do tempo.

\section{Resultados e Discussão}

O estudo foi aprovado pelo Comitê de Ética em Pesquisa da Faculdade de Odontologia de Piracicaba UNICAMP, pelo protocolo $n^{\circ}$ 157/2015.

A amostra selecionada foi de 62 clínicas odontológicas cadastradas no Sindicato dos Empregados em Estabelecimentos de Serviços de Saúde de Piracicaba e Região, localizado na cidade de Piracicaba, composto por 22 municípios. Quanto ao CNAE, do total $(n=62), 75,80 \%$ exercem atividade odontológica, 6,45\% está relacionado ao plano de saúde, $17,75 \%$ em outras atividades.

A filiação ao sindicato está dividida entre as duas últimas décadas, em que a maioria $(51,62 \%)$ pertence ao período de 2004 a 2010. Enquanto que as demais
$(48,38 \%)$, de 2011 a 2015. Em relação à data de fundação das clínicas junto às suas prefeituras, $17,75 \%$ se referem à década de 80 e de $90,53,22 \%$ iniciaram atividade entre 2000 e 2010 e $29,03 \%$ foram fundadas entre 2011 a 2015. Do universo de clínicas, apenas $32,25 \%$ continham pelo menos um ou mais processos trabalhistas em andamento. Todavia, do montante de processos, $27,13 \%$ estão concentrados em uma única clínica, 22,48\% em uma segunda e ainda outra está com $10 \%$. E em relação àquelas que possuem apenas um processo, totalizam $40 \%$ do total de clínicas envolvidas com processos trabalhistas.

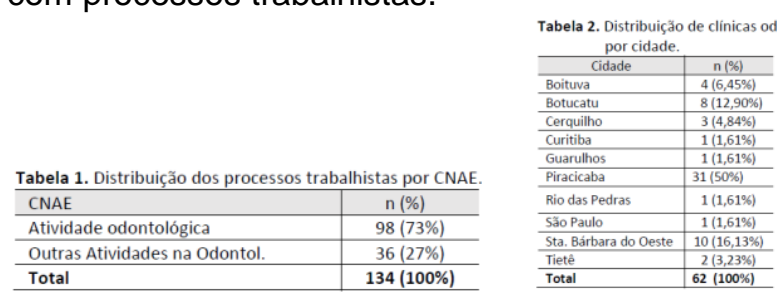

\section{Conclusões}

Constatou-se a abrangência do Sindicato dos Empregados em Estabelecimentos de Serviços de Saúde, visto que houve preferências de adesão, apesar da distância territorial e expressiva representatividade regional. Pode-se concluir que a filiação ao sindicato beneficiou a condução dos recentes processos trabalhistas. Este dado também conduz ao raciocínio que a lógica de beneficiamento pós-adesão sindical é mais intenso para as clínicas abertas nas duas últimas décadas. 